\title{
Screening and characterization of siderophore producing endophytic bacteria from Cicer arietinum and Pisum sativum plants
}

\author{
Rajat Maheshwari, Namita Bhutani, Pooja Suneja* \\ Department of Microbiology, Maharshi Dayanand University, Rohtak 124001, India
}

\begin{tabular}{l}
\hline ARTICLE INFO \\
\hline Article history: \\
Received on: March 10, 2019 \\
Accepted on: April 26, 2019 \\
Available online: September 10, 2019 \\
\hline
\end{tabular}

Key words:

Endophytes, plant growth promotion, siderophore, CAS

assay, tetrazolium, hydroxamate

\section{ABSTRACT}

Siderophores are low molecular weight iron chelating secondary metabolites synthesized by various groups of microorganisms help in scavenging iron-limited conditions. Siderophores produced by endophytic bacteria facilitate the plant growth by providing iron to plants. The objective of this study was to isolate and screen the siderophore producing endophytes from nodules and roots of Cicer arietinum and Pisum sativum plants. Out of total 84 isolates, only 14 endophytes produced siderophore and quantitative analysis was also done. Ten best siderophore producers (above 65\% siderophore units) were characterized for the type of siderophore produced. Most of them were producing hydroxamate and carboxylate type of siderophores. These 10 isolates were evaluated for other plant growth promoting (PGP) traits in vitro. All of them were producing ammonia and indole-3-acetic acid (IAA). Isolate CPFR10 was found to be positive for all the PGP traits viz. ammonia, organic acid, HCN, and IAA production. Diversity analysis of these 10 isolates using Amplified rDNA Restriction Analysis profile revealed nine genotypes at $90 \%$ similarity.
\end{abstract}

\section{INTRODUCTION}

Iron is the fourth most abundant element in the Earth's crust, vital for growth of living organisms as it acts as cofactor for enzymes involved in various metabolic processes [1,2]. Despite of its abundance in soil, it is unavailable to plants and microorganisms as it occurs as $\mathrm{Fe}^{3+}$ (ferric form) which is not soluble at physiological $\mathrm{pH}$ [3]. Microorganisms have developed specific mechanism for uptake of iron by releasing siderophores to scavenge iron. Siderophores are low molecular weight iron chelating compound which mainly functions to arrest insoluble ferric iron from different environments [4]. Large numbers of bacterial genera are known to synthesize siderophores, such as Pseudomonas, Azotobacter, Bacillus, Rhizobium, and Enterobacter. [5]. Although siderophores mainly scavenge iron but in addition to this, they have some other functions also. They help the microbes

\footnotetext{
*Corresponding Author

Pooja Suneja, Department of Microbiology,

Maharshi Dayanand University, Rohtak 124001, India.

E-mail:poojapavit@gmail.com
}

in acquiring mineral nutrients, function as virulence factors to protect them from pathogens $[6,7]$.

Endophytes either fungi or bacteria resides inside plant tissues without causing any harm to their host [8]. They receive nutrients and protection from their host and in turn promote the growth of the host plant [9]. The plant growth promoting effect of endophytes occurs through the concerted activity of phytohormones production, biological nitrogen fixation, phosphate solubilization, modulation of 1-aminocyclopropane-1-carboxylic acid (ACC) deaminase expression, production of siderophores, and biocontrol [10]. Among these, the siderophore production by endophytes helps the plants in iron sequestration and increases the concentration of bio available iron to inner tissues [11]. In addition to iron acquisition, they also give nutritional competition to the pathogens by limiting the iron availability to them and inhibit their growth [6]. Various studies have demonstrated the ability of siderophore producing endophytes in plant growth promotion. Upon inoculation of Mung bean plants with siderophore-producing Pseudomonas strain GRP3, chlorotic symptoms were reduced and chlorophyll content increased under iron-limiting environments [12]. The siderophore producing Pseudomonas fluorescens C7 
facilitated the iron uptake and improved the growth of Arabidopsis thaliana plants [13]. Large number of studies have also reported siderophore producing endophytes lessen the environmental stresses forced on plants by high level of heavy metals in soil [14].

Siderophores, the metal-chelating agents produced by large number of bacteria under iron-destitute state, are mainly grouped into three types: hydroxamates, catecholates, and carboxylates [15]. Hydroxamate type of siderophore comprises linear and cyclic compound with 1-amino-5-hydroxaminopentane which binds to iron with binding constants of $10^{22}$ to $10^{32} \mathrm{M}^{-1}$ [16]. Due to this robust binding and hexadentate structure, hydroxamates are unaffected to environmental degradation and enzymatic hydrolysis [16]. These types of siderophores are reported to be produced by both Gram-positive as well as Gram-negative bacterial genera, such as Streptomyces spp., aerobactin by Escherichia coli, ferrioxamines and ferribactin by Pseudomonas sp., Arthrobacter spp. [17]. Carboxylate type of siderophores like rhizobactin and staphyloferrin A are predominantly produced by Rhizobium and Staphylococcus, respectively. The catecholate (or phenolate) form of siderophore is known to be produced by bacterial genera, such as E. coli, Klebsiella sp., Bacillus sp., Erwinia sp., and Salmonella sp. [18]. For chelating iron, each catecholate group provides two oxygen atoms to form hexadentate octahedral complex. These types are characterized by high stability constants that can bind iron even at very low concentration. Most common examples are enterobaction, enterochelin, mycobactins, and agrobactins [2]. Therefore, the present investigation was planned to qualitatively and quantitatively screen siderophore producing endophytic bacteria from roots and nodules of Cicer arietinum and Pisum sativum plants and to study their genetic diversity using Amplified rDNA Restriction Analysis (ARDRA) profile.

\section{MATERIALS AND METHODS}

\subsection{Collection of Plant Material and Isolation of Bacterial Endophytes}

Cicer arietinum and Pisum sativum plant samples were collected randomly from the fields of Sirsa and Fatehabad district of Haryana, India. After uprooting plants, nodule and root samples were washed thoroughly in running tap water to remove any adhering soil. Samples were surface sterilized by sequential immersion in $0.25 \%$ $\mathrm{HgCl}_{2}$ for 1 minute, $95 \%$ ethanol for 30 seconds, then washing five times with sterile double distilled water [19]. Sterilized roots and nodules were crushed using sterile glass rod and sap was streaked on Tryptone soy agar (TSA) plates and incubated for 2-3 days at $28^{\circ} \mathrm{C} \pm 2{ }^{\circ} \mathrm{C}$. Colonies were selected on the basis of variation in morphology (color, size, and shape), purified, maintained on agar slants at $4^{\circ} \mathrm{C}$ and glycerol stocks at $-20^{\circ} \mathrm{C}$.

\subsection{Screening of Siderophore Production}

The siderophore production capability of isolates was detected on Chrome azurol S (CAS) agar plates for qualitative assay [20]. Isolates were grown initially in tryptone soy broth (TSB) for 24 hours on rotatory shaker with $150 \mathrm{rpm}$ at $28^{\circ} \mathrm{C} \pm 2^{\circ} \mathrm{C}$. Then $50 \mu \mathrm{l}$ of bacterial suspension was spotted on CAS agar plates and incubated for $4-5$ days at $28 \pm 2{ }^{\circ} \mathrm{C}$. Following incubation, these plates were observed for production of yellow-orange halo zone around the spot which indicates siderophore production.

\subsection{Quantitative Estimation of Siderophore Production}

Isolates found to be positive for siderophore production were screened quantitatively using CAS liquid assay [21]. After initial growth in TSB, isolates were transferred to siderophore inducing medium (SIM) and incubated for 5 days on rotatory shaker with 200 $\mathrm{rpm}$ at $28 \pm 2^{\circ} \mathrm{C}$. SIM was prepared as follows [22], Solution-1, 30.2 $\mathrm{g}$ of Piperazine-N,N'-bis(2-ethanesulphonic acid) buffer dissolved in $750 \mathrm{ml}$ of salts solution containing $\mathrm{KH}_{2} \mathrm{PO}_{4}(0.3 \mathrm{~g}), \mathrm{NaCl}(0.5$ g) and $\mathrm{NH}_{4} \mathrm{Cl}(1 \mathrm{~g})$. Iron free solution-2 was prepared with glucose (2 g), mannitol (2 g), MgSO4.7H2O (493 mg), CaCl $(11 \mathrm{mg})$, $\mathrm{MnSO}_{4} \cdot \mathrm{H}_{2} \mathrm{O}(1.17 \mathrm{mg}), \mathrm{H}_{3} \mathrm{BO}_{3}(1.4 \mathrm{mg}), \mathrm{CuSO}_{4} .5 \mathrm{H}_{2} \mathrm{O}(0.04 \mathrm{mg})$, $\mathrm{ZnSO}_{4} .7 \mathrm{H}_{2} \mathrm{O}(1.2 \mathrm{mg})$, and $\mathrm{NaMoO}_{4} \cdot 2 \mathrm{H}_{2} \mathrm{O}(1 \mathrm{mg})$. Solutions 1 and 2 were then autoclaved at $15 \mathrm{lb} /$ inch $^{2}$ for 15 minutes. Solution 3 was prepared by dissolving casamino acid $(10 \% \mathrm{w} / \mathrm{v})$ in distilled water, i.e., $3 \mathrm{~g}$ in $27 \mathrm{ml}$ of water and dissolved thoroughly on magnetic stirrer. The solution was filter sterilized using 0.2 micron membrane filter. Finally, solutions 2 and 3 were mixed into solution 1 and volume was adjusted to 11 with $\mathrm{pH} 6.8$ and dispensed into flasks ( $50 \mathrm{ml}$ per flask). All the glassware were deferrated by washing with 6-M $\mathrm{HCl}$ overnight to eliminate the residual $\mathrm{Fe}$ contamination, then rinsed with double distilled water two to three times. The solutions were deferrated using 8-hydroxyquinoline followed by extraction with chloroform. Following incubation of 5 days, cells were discarded by centrifugation at 7,000 rpm for 15 minutes. Resultant supernatant $(0.5 \mathrm{ml})$ was mixed with the $0.5 \mathrm{ml} \mathrm{CAS}$ assay solution [21]; $10 \mu \mathrm{l}$ of shuttle solution (2 M 5 -sulfosalicyclic acid) was added. After 20 minutes of incubation at room temperature, absorbance was measured at $630 \mathrm{~nm}$ to estimate the loss of blue color to orange. The percentage of siderophore units were calculated by the formula:

$$
\left[\left(A_{r}-A_{s}\right) / A_{r}\right] \times 100
$$

where, $A_{r}$ is the absorbance of reference sample at 630 nm (medium plus CAS assay solution and shuttle solution) and $A_{s}$ is the absorbance of sample (supernatant plus CAS assay solution and shuttle solution).

\subsection{Chemical Characterization of Siderophores}

The type of siderophore was determined by specific tests using culture supernatants prepared as described above. Hydroxamate type of siderophore was detected by tetrazolium test [23] and spectrophotometric assay at 420-450 nm [24], catecholate type of siderophores was detected by Arnow's test and spectrophotometric assay at $495 \mathrm{~nm}[24,25]$; carboxylate type was detected using Shenker assay [26] and chemical test [27].

\subsection{Characterization of Plant Growth Promoting Traits}

Ammonia and organic acid production were evaluated by nesslerization reaction and methyl red test, respectively [28]. Phosphate solubilization was checked by spotting the isolate on Pikovskaya agar medium plates and incubated for $4-5$ days at $28^{\circ} \mathrm{C}$ $\pm 2^{\circ} \mathrm{C}$ [29]. The plates were observed for the development of clear halo zone around colonies. Hydrogen cyanide $(\mathrm{HCN})$ production 
was estimated using method as described by Lorck [30]. Bacterial isolates were spreaded on nutrient agar plates supplemented with glycine. Whatman filter paper no. 1 disks (dipped in $0.5 \%$ picric acid, $2 \%$ of sodium carbonate) were placed on lids of the petri plates and sealed with the parafilm. Change in color from yellow to dark brown of the filter paper indicates the production of HCN after 4-5 days of incubation at $28^{\circ} \mathrm{C} \pm 2{ }^{\circ} \mathrm{C}$. The production of IAA in the culture broth was determined by using standard colorimetric assay [31]. The isolates were grown in Erlenmeyer flasks $(150 \mathrm{ml})$ containing $25 \mathrm{ml}$ of sterilized Yeast extract mannitol (YEM) broth supplemented with $0.1 \mathrm{~g} / 1 \mathrm{~L}$-tryptophan and incubated at $28^{\circ} \mathrm{C} \pm 2^{\circ} \mathrm{C}$ for 5 days in a shaking incubator at $150 \mathrm{rpm}$. Following incubation, culture broths were centrifuged at 7,000 rpm for 3 minutes and the supernatant was mixed in equal volume with Salkowski reagent $\left(1 \mathrm{ml} 0.5 \mathrm{M} \mathrm{FeCl}_{3}\right.$ in $50 \mathrm{ml}$ of $35 \% \mathrm{HClO}_{4}$ ). After an incubation of 30 minutes in dark, absorbance was measured at $530 \mathrm{~nm}$ and IAA concentration of the samples was evaluated using standard curve of known concentration of IAA (10-200 $\mu \mathrm{g} / \mathrm{ml})$ [32]. Two milliliters of uninoculated YEM broth with $2 \mathrm{ml}$ of Salkowski reagent was taken as a negative control.

\subsection{Amplified rDNA Restriction Analysis (ARDRA) of Potent Siderophore Producers}

The genomic DNA from selected isolates was extracted by modified CTAB method [33] and used as template for PCR amplification of $16 \mathrm{~S}$ rDNA. The universal primers were used for amplification 8F (5'AGAGTTTGATCCTGGCTCAG3') and 1541R (5'AAGGAGGTGATCCAGCCGCA3') [34]. PCR amplifications were performed in a volume of $30 \mu \mathrm{l}$ containing 50 ng DNA template, $1 \times$ Taq polymerase buffer, $0.25 \mu \mathrm{M}$ of each primers, $0.2 \mathrm{mM}$ of each dNTP, $1.5 \mathrm{mM} \mathrm{MgCl}_{2}$ and $1 \mathrm{U}$ of Taq polymerase (Promega, USA). Amplification was performed in the thermocycler (Bio-Rad, T100, USA) with the initial denaturation of $94^{\circ} \mathrm{C}$ for 3 minutes followed by 30 cycles of $94^{\circ} \mathrm{C}$ for 45 seconds, $58^{\circ} \mathrm{C}$ for 45 seconds, $72^{\circ} \mathrm{C}$ for 2 minutes, and final extension of $72^{\circ} \mathrm{C}$ for 7 minutes. Amplified PCR product was resolved on $1.2 \%$ agarose gel in $0.5 \times \mathrm{TBE}$ buffer at $60 \mathrm{~V}$ for 40 minutes stained with ethidium bromide under Azure c150 gel documentation system (Azure biosystems, Dublin, CA 94568). PCR products were digested separately with three restriction endonucleases HinfI, HaeIII, and MspI (Promega Corp., USA) in a $25-\mu 1$ reaction volume. Restriction digested product were resolved on $1.5 \%$ agarose gels along with 100 bp marker (Promega Corp., USA) and run at $60 \mathrm{~V}$ in $1 \times$ tris-borate-EDTA (TBE) buffer containing $10 \mu \mathrm{g} / \mathrm{ml}$ ethidium bromide. Using SimQual (Jaccard coefficient), similarity matrices were constructed and clustering was done by unweighted pair grouping with mathematic average (UPGMA) method using NTSYS-pc program (Version2.1: Exeter software, Setauket, NY) [35].

\section{RESULTS}

\subsection{Isolation of Bacterial Endophytes}

A total of 84 morphologically distinct endophytic bacteria; 52 from Chickpea (Cicer arietinum) and 32 from Pea (Pisum sativum) plants were isolated from surface sterilized root and nodules and purified by subculturing. Forty-six isolates were obtained from nodules and 38 from roots. Out of total, $57 \%$ of the isolates were
Gram-positive and rest Gram-negative (Tables 1 and 2). All the bacterial isolates exhibited variable colony and cell morphology.

\subsection{Qualitative and Quantitative Screening of Siderophore Producing Endophytic Bacteria}

Out of total, 14 isolates were found to be positive for siderophore and selected for quantitative estimation of siderophore production (Figs. 1 and 2). Four isolates produced siderophore units in the range of $1.44 \%-14.04 \%$, while 10 isolates PFR5, CPFR10, CPFR4, CPFR18, PFR12, CPFN16, CPFN8, PFN14, CPFN11, and CPSR6 produced significantly higher quantities of siderophores above $65 \%$ siderophore units (Table 1).

\subsection{Characterization of Type of Siderophore}

Selected 10 bacterial isolates with significant siderophore production were characterized for type of siderophore produced (Table 2). Eight isolates, CPSR6, CPFN8, CPFN11, CPFN16, CPFR4, PFR5, PFR12, and PFN14 showed maximum peak between 420 and $450 \mathrm{~nm}$ in the $\mathrm{FeCl}_{3}$ test and deep red color in the tetrazolium test which indicates hydroxamate type of siderophore. Only one isolate, CPFR10 showed absorbance peak at $495 \mathrm{~nm}$ in the $\mathrm{FeCl}_{3}$ test and reddish color in Arnow's assay indicated catecholate type of siderophore. Ten isolates, namely, CPSR6, CPFN8, CPFN11, CPFN16, CPFR4, CPFR10, CPFR18, PFR5, PFR12, and PFN14 were positive for carboxylate type of siderophore showed maximum peak between 190 and $280 \mathrm{~nm}$. It was observed that isolates CPSR6, CPFN8, CPFN11, CPFN16, CPFR4, PFR5, PFR12, and PFN14 were positive for both the hydroxamate as well as carboxylate types of siderophore.

\subsection{Plant Growth Promoting Properties of Siderophore Producing Endophytes}

All these 10 siderophore producers were assessed for their plant growth promoting capability. All the isolates were able to produce IAA in the range of $11.12-68.46 \mu \mathrm{g} / \mathrm{ml}$ and ammonia. Only two

Table 1: Percentage siderophore production by endophytic bacterial isolates from Cicer arietinum and Pisum sativum.

$\begin{array}{ccc}\text { Isolates } & \text { Siderophore production } & \begin{array}{c}\text { \% Siderophore } \\ \text { production (CAS assay) }\end{array} \\ \text { CPSN1 } & + & 14.04 \pm 0.42 \\ \text { CPSN2 } & + & 8.56 \pm 1.10 \\ \text { CPSN6 } & + & 1.44 \pm 0.80 \\ \text { CPFN8 } & ++ & 87.03 \pm 0.18 \\ \text { CPFN11 } & ++ & 73.10 \pm 2.19 \\ \text { CPFN16 } & ++ & 88.26 \pm 0.53 \\ \text { CPSR1 } & + & 2.57 \pm 0.70 \\ \text { CPSR6 } & ++ & 67.28 \pm 1.53 \\ \text { CPFR4 } & +++ & 91.33 \pm 0.34 \\ \text { CPFR10 } & +++ & 91.78 \pm 0.46 \\ \text { CPFR18 } & ++ & 90.41 \pm 0.91 \\ \text { PFN14 } & ++ & 83.01 \pm 1.36 \\ \text { PFR5 } & +++ & 92.93 \pm 0.28 \\ \text { PFR12 } & +++ & 90.41 \pm 0.71\end{array}$


isolate CPFR4 and PFR5 were able to solubilize phosphate. Isolate CPFR10 possessed multi plant growth promoting (PGP) traits and was found to be best ammonia, organic acid and IAA producer among all (Table 3).

\subsection{Amplification of $16 S$ rDNA and ARDRA Profile Analysis}

Genomic DNA of these isolates were amplified by PCR using 16S rDNA primers, fD1 (5'AGAGTTTGATCCTGGCTCAG3') and $\mathrm{rD1}$ (5' AAGGAGGTGATCCAGCC 3'). Amplification of $16 \mathrm{~S}$ rDNA was confirmed by obtaining single band of $\sim 1,400 \mathrm{bp}$ on $1.2 \%(\mathrm{w} / \mathrm{v})$ agarose gel. The RFLP pattern of $16 \mathrm{~S}$ rDNA of 10 selected bacterial isolates from chickpea and pea showed 24 polymorphic bands ranging from 170 to $1,300 \mathrm{bp}$. The dendrogram of similarity coefficients was constructed which depicted that all the isolates formed nine clusters at $90 \%$ similarity (Fig. 3). The isolates CPFN8, CPFR4 were grouped in cluster 1 showed $100 \%$ similarity, while all the other isolates were present in separate eight clusters. Isolate CPSR6 is out-grouped in the ninth clusters showing its variation with other isolates.

Table 2: Characterization of siderophore type by endophytic bacterial isolates.

\begin{tabular}{|c|c|c|c|c|c|}
\hline \multirow[b]{2}{*}{ Isolates } & \multicolumn{2}{|c|}{$\mathrm{FeCl}_{3}$ test } & \multirow[b]{2}{*}{$\begin{array}{c}\text { Hydroxamate } \\
\text { (Tetrazolium test) }\end{array}$} & \multirow{2}{*}{$\begin{array}{l}\text { Catecholate } \\
\text { (Arnow's test) }\end{array}$} & \multirow[b]{2}{*}{ Carboxylate } \\
\hline & $\begin{array}{l}\text { Peak at } 425 \mathrm{~nm} \\
\text { (Hydroxamate) }\end{array}$ & $\begin{array}{c}\text { Peak at } 495 \mathrm{~nm} \\
\text { (catecholate) }\end{array}$ & & & \\
\hline CPSR6 & + & - & + & - & + \\
\hline CPFN8 & + & - & + & - & + \\
\hline CPFN11 & + & - & + & - & + \\
\hline CPFN16 & + & - & + & - & + \\
\hline CPFR4 & + & - & + & - & + \\
\hline CPFR10 & - & + & - & + & + \\
\hline CPFR18 & - & - & - & - & + \\
\hline PFR5 & + & - & + & - & + \\
\hline PFR12 & + & - & + & - & + \\
\hline PFN14 & + & - & + & - & + \\
\hline
\end{tabular}
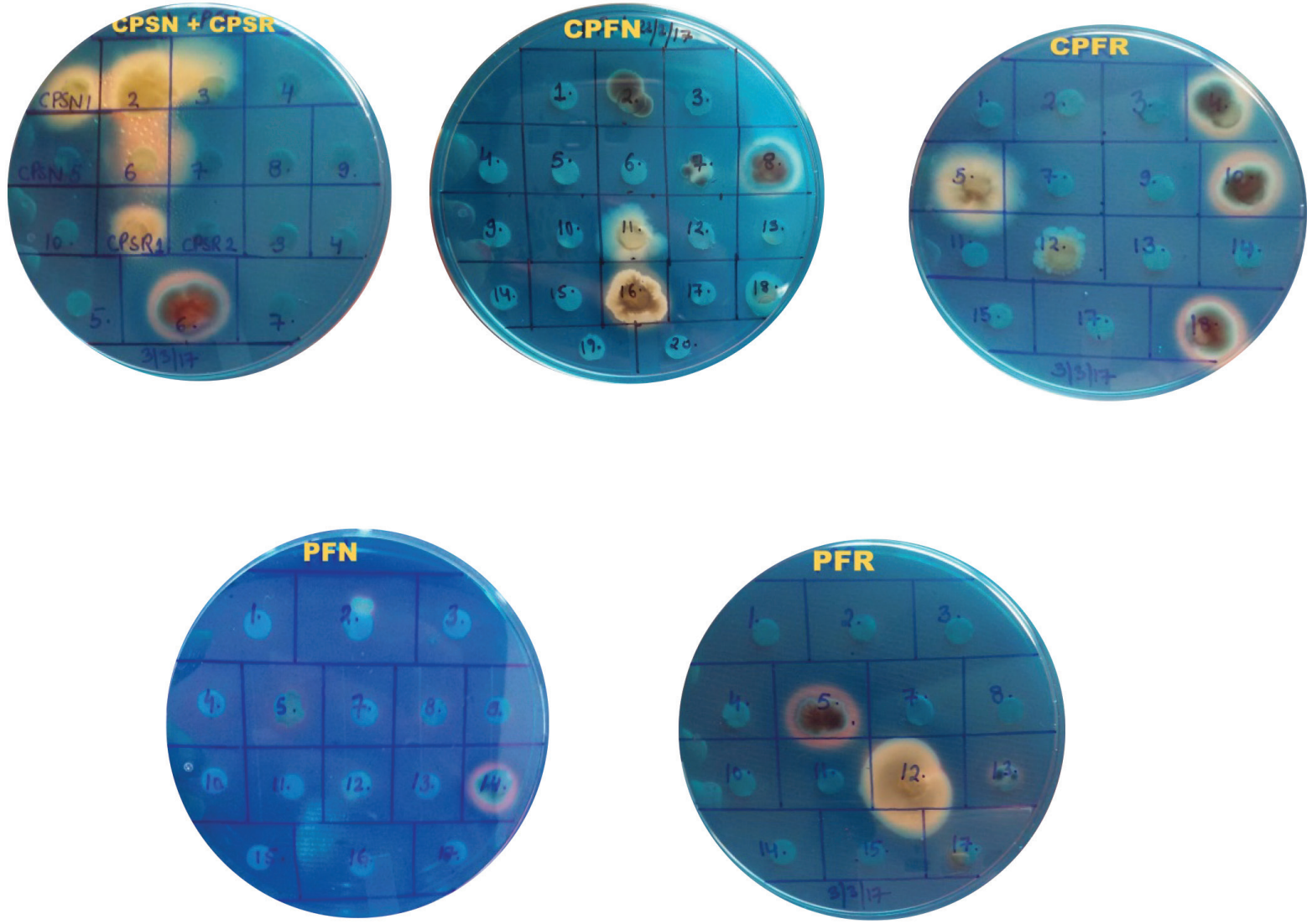

Figure 1: Siderophore production by endophytic bacteria on CAS agar plates. 


\section{DISCUSSION}

Endophytic bacteria are ubiquitous in almost all the plant species; actively colonizing healthy plant tissue with no apparent symptoms of diseases [10]. They offer numerous benefits to host plant by producing primary and secondary metabolites, providing resistance against phytopathogens, augmenting tolerance to stress conditions and helping in sequestration of nutrients to plants [2]. The growing knowledge on the favorable effects of endophytes on plant growth has recognized these as useful tools on the way to improve crop yield in addition to more sustainable and chemical free agriculture. Several studies on rhizobial as well as non-rhizobial endophytic bacterial genera during the last two decades have acknowledged their role in plant growth promotion $[12,13,36]$.

In this study, total of 84 endophytic bacterial isolates from nodules and roots of $C$. arietinum and $P$. sativum plants were screened for siderophore production. Fourteen isolates with most halozones diameters were selected and quantified. Production of siderophores is an important attribute of plant growth promoting endophytes and facilitates growth of plants under iron limiting conditions through iron sequestration [2]. There are many reports in literature on siderophore producing capacity of endophytes affirmed using CAS assay [37-39].

Out of 14, 10 isolates were producing siderophore units above $65 \%$ in CAS-liquid assay. Siderophores produced by microorganisms are usually classified as catecholates, hydroxamates, carboxylates, and mixed type. A range of biochemical assays were used for determining siderophore type $[23,24,40]$. Most of our isolates were positive for hydroxamate type of siderophore. Earlier studies also reported that several soil bacteria could produce more than one type of hydroxamates [6]. The catecholate type of siderophore was detected by Arnow's test and $\mathrm{FeCl}_{3}$ test. Only one of the isolate CPFR10 produced catecholate type of siderophore.

The carboxylate type of siderophores was detected by formation of copper complex between the range of 190-280 nm. In the present study, all the isolates showed peak in the range of 190-280 nm with copper colored complex showing the presence of carboxylate type of siderophore. The type of siderophore synthesized by bacteria depends on the amount and accessibility of nutrients and it may differ in culture rich conditions as compared to natural habitat. Previous studies have reported that the bacteria are capable of producing one or more types of siderophores, hydroxamate, and catecholate being the most common types [4143], but in contrary to this, our isolates produced both carboxylate and hydroxamate type of siderophores.

The selected best 10 siderophore producers were further investigated for their in vitro plant growth promoting traits and diversity analysis. The ARDRA technique has been commonly used to study the molecular diversity of endophytic plant growth

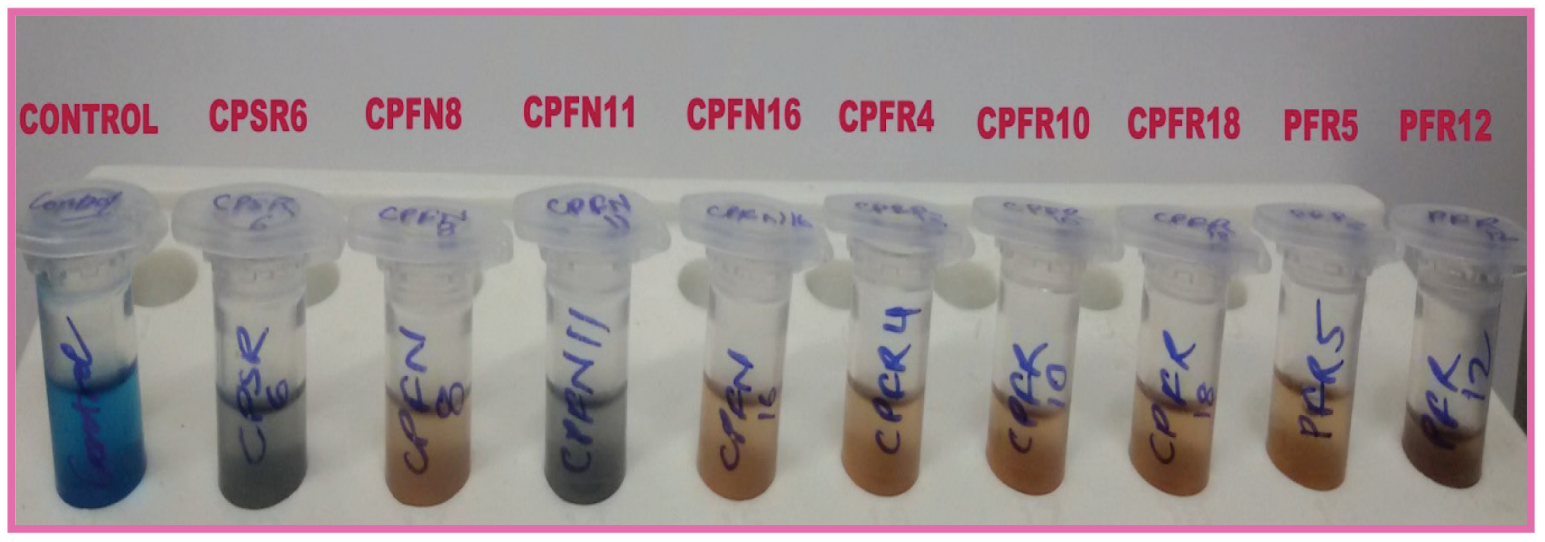

Figure 2: Chrome azurol S liquid assay to quantify siderophore production.

Table 3: PGP traits of best siderophore producers.

\begin{tabular}{|c|c|c|c|c|c|}
\hline Isolates & $\mathrm{NH}_{3}$ production & $\begin{array}{l}\text { Organic acid } \\
\text { production }\end{array}$ & HCN production & $P_{2}$ solubilization & IAA $(\mu \mathrm{g} / \mathrm{ml})$ \\
\hline CPSR6 & + & - & - & - & $18.29 \pm 2.26$ \\
\hline CPFN8 & +++ & - & + & - & $25.29 \pm 5.50$ \\
\hline CPFN11 & +++ & - & - & - & $11.12 \pm 1.56$ \\
\hline CPFN16 & ++ & - & - & - & $31.38 \pm 3.64$ \\
\hline CPFR4 & ++ & - & + & + & $27.37 \pm 3.92$ \\
\hline CPFR10 & +++ & +++ & + & - & $68.46 \pm 2.40$ \\
\hline CPFR18 & +++ & - & - & - & $37.42 \pm 4.44$ \\
\hline PFR5 & ++ & - & - & + & $35.13 \pm 1.71$ \\
\hline PFR12 & +++ & - & - & - & $37.63 \pm 1.79$ \\
\hline PFN14 & ++ & + & - & - & $26.17 \pm 0.65$ \\
\hline
\end{tabular}




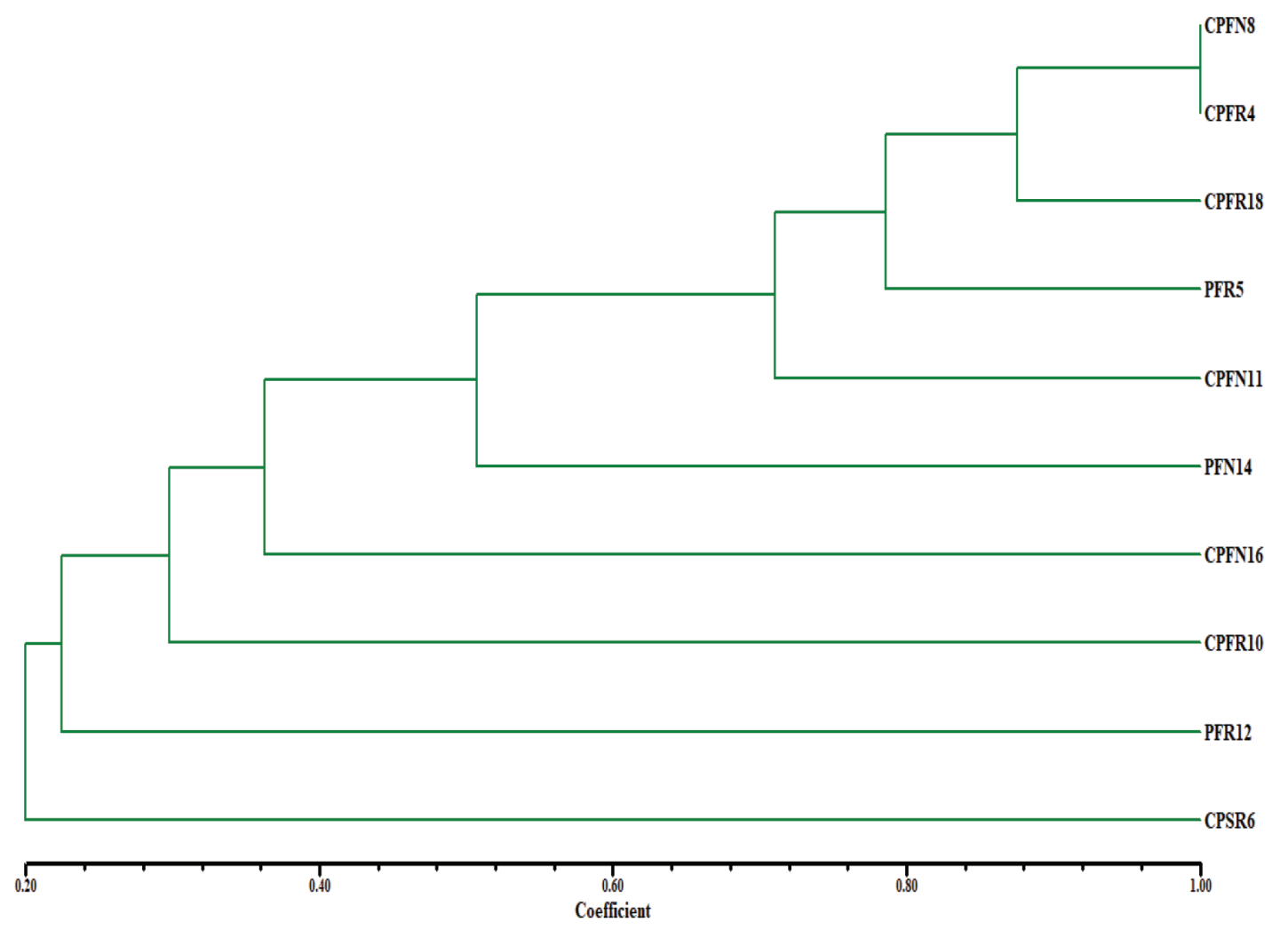

Figure 3: Dendrogram showing phenotypic similarity of siderophore producing endophytic bacteria from Cicer arietinum and Pisum sativum using UPGMA method.

promoting bacteria. The genetic diversity of siderophore producing endophytic bacteria using ARDRA resulted in grouping of these isolates in nine separate clusters at $90 \%$ similarity representing nine different genotypes. Similarly, several biotypes of endophytic bacteria in different legumes crops have also been reported by others [50-52]. Plant growth promoting ability of endophytes offers numerous benefits to host plant and help to survive under diverse environmental conditions $[10,41,44]$. Isolate CPFR10 was found to be most promising with multi PGP traits along with high IAA and HCN production. The ability to produce IAA promotes plant growth and elicits an increased level of protection during adverse conditions $[45,46]$. HCN production is regarded as one of the recognized host's biocontrol or protecting mechanism against phytopathogens [47]. Several microorganisms producing siderophore along with HCN are known to suppress the growth of pathogens [48-50]. The microbes having $\mathrm{HCN}+$ phenotype along with siderophore and IAA production can be expected to have an ecological role not only in biocontrol but also in regulating the bioavailability of nutrients.

\section{CONCLUSION}

A total of 84 endophytic bacteria isolated from nodules and roots of Cicer arietinum and Pisum sativum plants were screened for siderophore production. Following qualitative CAS agar assay, 14 isolates produced siderophore and selected for further investigation. Upon quantitative analysis, 10 isolates produced siderophore above $65 \%$ siderophore units and subsequently characterized for the type of siderophore. Most of them produced both carboxylate and hydroxamate type of siderophores. The ability to produce different types of siderophores with differences in structure and iron binding/ releasing capacities, enable these microbes to have multiple roles depending upon the habitats. The present investigation revealed that these endophytic bacterial isolates also exhibited other plant growth promoting traits viz. ammonia, organic acid, IAA, HCN production, and phosphate solubilization. However, to ascertain the effectivity of PGP traits on growth and productivity of crops, through phytohormone production and control against harmful microbes, needs to be evaluated in further studies.

\section{ACKNOWLEDGMENTS}

The authors would like to thank the Department of Science \& Technology (DST), Govt. of India, New Delhi for financial support to undertake these investigations.

\section{CONFLICT OF INTEREST}

The authors declare that they have no conflict of interest.

\section{REFERENCES}

1. Gamit DA, Tank SK. Effect of siderophore producing microorganism on plant growth of Cajanus cajan (Pigeon pea). Int J Res Pure Appl Microbiol 2014;4:20-7.

2. Saha M, Sarkar S, Sarkar B, Sharma BK, Bhattacharjee S, Tribedi P. Microbial siderophores and their potential applications: a review. Environ Sci Pollut Res 2016;23:3984-99.

3. Bou-Abdallah F. The iron redox and hydrolysis chemistry of the ferritins. Biochim Biophys Acta 2010;1800(8):719-31. 
4. Lacava PT, Silva-Stenico ME, Araújo WL, Simionato AVC, Carrilho E, Siu MT, et al. Detection of siderophores in endophytic bacteria Methylobacterium spp. associated with Xylella fastidiosa subsp. pauca. Pesqui Agropecu Bras 2008;43:521-8.

5. Wittenwiler M. Mechanisms of iron mobilization by siderophores. Master Studies in Environmental Sciences Master, ETH Zürich, 2007.

6. Ahmed E, Holmström SJM. Siderophore production by microorganisms isolated from a Podzol soil profile. Geomicrobiol J 2015;32:397-411.

7. Lamont BB, Pérez-Fernández $\mathrm{M}$. Total growth and root-cluster production by legumes and proteas depends on rhizobacterial strain, host species and nitrogen level. Ann Bot 2016;118:725-32.

8. Ryan RP, Germaine K, Franks A, Ryan DJ, Dowling DN. Bacterial endophytes: recent developments and applications. FEMS Microbiol Lett 2008;278:1-9.

9. Dudeja SS, Giri R, Saini R, Suneja-Madan P, Kothe E. Interaction of endophytic microbes with legumes. J Basic Microbiol 2012;52:248-60.

10. Santoyo G, Moreno-Hagelsieb G, del Carmen Orozco-Mosqueda M, Glick BR. Plant growth-promoting bacterial endophytes. Microbiol Res 2016;183:92-9.

11. Dimkpa C. Microbial siderophores: production, detection and application in agriculture and environment. Endocytobiosis Cell Res 2016;27:7-16.

12. Sharma A, Johri BN, Sharma AK, Glick BR. Plant growth-promoting bacterium Pseudomonas sp. strain GRP3influences iron acquisition in mung bean (Vigna radiata L. Wilzeck). Soil Biol Biochem 2003;35:887-94.

13. Vansuyt G, Robin A, Briat JF, Curie C, Lemanceau P. Iron acquisition from Fe-pyoverdine by Arabidopsis thaliana. Mol Plant Microbe Interact 2007;20(4):441-7.

14. Burd GI, Dixon DG, Glick BR. Plant growth-promoting bacteria that decrease heavy metal toxicity in plants. Can J Microbiol 2000;46(3):237-45.

15. Rungin S, Indananda C, Suttiviriya P, Kruasuwan W, Jaemsaeng R, Thamchaipenet A. Plant growth enhancing effects by a siderophoreproducing endophytic streptomycete isolated from a Thai jasmine rice plant (Oryza sativa L. cv. KDML105). Int J Gen Mol Microbiol 2012;102:463-72.

16. Winkelmann G. Ecology of siderophores with special reference to the fungi. Biometals 2007;20(3-4):379.

17. Cornelis P. Iron uptake and metabolism in pseudomonads. App microbiol Biot 2010;86(6):1637-45.

18. Crosa JH, Mey AR, Payne SM, editors. Iron transport in bacteria. ASM Press, Washington, DC, 2004.

19. Vincent JM. A Manual for the Practical Study of Root-Nodule Bacteria. Blackwell Scientific Publications, Oxford Press, Edinburgh; 1970

20. Schwyn B, Neilands JB. Universal chemical assay for the detection and determination of siderophores. Anal Biochem 1987;160:47-56.

21. Payne SM. Detection, isolation, and characterization of siderophores. Methods Enzymol 1994;235:329-44.

22. Alexander DB, Zuberer DA. Use of chrome azurol S reagents to evaluate siderophore production by rhizosphere bacteria. Biol Fertil Soils 1991;12:39-45.

23. Snow GA. Mycobactin. A growth factor for Mycobacterium johnei. Part II. Degradation, and identification of fragments. J Chem Soc (Resumed) 1954;2588-96.

24. Neilands JB. Microbial Iron Compounds. Annu Rev Biochem 1981; 50:715-731.

25. Arnow L. Colorimetric determination of the components of 3 , 4-dihydroxyphenylalaninetyrosine mixtures. J Biol Chem 1937;118 531-537.

26. Shenker M, Chen Y, Oliver I, Helmann M, Hadar Y. Utilization by tomatoes of iron mediated by a siderophore produced by Rhizopus arrhizus. J Plant Nutr 1992;15:2173-82.

27. Vogel AL. Class reactions (reactions for functional groups). In: Elementary practical organic chemislly. CBS Publishers, New Delhi, p. 190, 1992.
28. Cappucino JC, Sherman N. In: Microbiology: a laboratory manual 3rd edition, Benjamin/Cumming Pub. Co., New York, NY, 1992.

29. Pikovskaya RI. Mobilization of phosphorus in soil in connection with vital activity of some microbial species. Mikrobiologiya 1948;17:36270 .

30. Lorck H. Production of hydrocyanic acid by bacteria. Physiol Plant 1948;1:142-6.

31. Tang YW, Bonner J. The enzymatic inactivation of indole acetic acid. II. The physiology of the enzyme. Am J Bot 1948;35:570-8.

32. Gordon SA, Weber RP. Colorimetric estimation of inodoleacetic acid. Plant Physiol 1951;26:192-5.

33. Ausubel FM, Brent R, Kingston RE, Moore DD, Seidman JG, Smith JA, et al. Short protocols in molecular biology. Chap 2.4. Wiley, New York, 1995

34. Weisburg WG, Barns SM, Pelletier DA, Lane DJ. 16S ribosomal DNA amplification for phylogenetic study. J Bacteriol 1991;173:697-703.

35. Rohlf FJ. On applications of geometric morphometrics to studies of ontogeny and phylogeny. Syst Biol 1998;47:147-58.

36. Saini R, Kumar V, Dudeja SS, Pathak DV. Beneficial effects of inoculation of endophytic bacterial isolates from roots and nodules in Chickpea. Int J Curr Microbiol Appl Sci 2015;4:207-21.

37. Liaqat F, Eltem R. Identification and characterization of endophytic bacteria isolated from in vitro cultures of peach and pear rootstocks. 3 Biotech 2016;6:2-9.

38. Ghavami N, Alikhani HA, Pourbabaei AA, Besharati H. Effects of two new siderophore-producing rhizobacteria on growth and iron content of maize and canola plants. J Plant Nutr 2017;40:736-46.

39. Rashid S, Charles TC, Glick BR. Isolation and characterization of new plant growth-promoting bacterial endophytes. Appl Soil Ecol 2012;61:217-24.

40. Dave BP, Dube HC. Detection and chemical characterisation of siderophores of rhizobacterial fluorescent Pseudomonas. Indian Phytopathol 2000;53:97-8.

41. Farokh RZ, Sachdev D, Pour NK, Engineer A, Pardesi KR, Zinjarde $\mathrm{S}$, et al. Characterization of plant-growth-promoting traits of Acinetobacter species isolated from rhizosphere of Pennisetum glaucum. J Microbiol Biotechnol 2011;21:556-66.

42. Kumar P, Thakur S, Dhingra GK, Singh A, Pal MK, Harshvardhan $\mathrm{K}$, et al. Inoculation of siderophore producing rhizobacteria and their consortium for growth enhancement of wheat plant. Biocatal Agric Biotechnol 2018;15:264-9.

43. Khan A, Singh P, Srivastava A. Synthesis, nature and utility of universal iron chelator-Siderophore: a review. Microbiol Res 2018;212-3, 103-11.

44. Gaiero JR, McCall CA, Thompson KA, Day NJ, Best AS, Dunfield KE. Inside the root microbiome: Bacterial root endophytes and plant growth promotion. Am J Bot 2013;100: $1738-50$.

45. Defez R, Andreozzi A, Bianco C. The overproduction of indole3 -acetic acid (IAA) in endophytes upregulates nitrogen fixation in both bacterial cultures and inoculated rice plants. Microb Ecol 2017;74:441-52.

46. Bhutani N, Maheshwari R, Negi M, and Suneja P. Optimization of IAA production by endophytic Bacillus spp . from Vigna radiata for their potential use as plant growth promoters. Isr J Plant Sci 2018 65:1-2.

47. Passari AK, Mishra VK, Leo VV, Gupta VK, Singh BP. Phytohormone production endowed with antagonistic potential and plant growth promoting abilities of culturable endophytic bacteria isolated from Clerodendrum colebrookianum Walp. Microbiol Res 2016;193:57-73.

48. Rijavec T, Lapanje A. Cyanogenic Pseudomonas spp. strains are concentrated in the rhizosphere of alpine pioneer plants. Microbiol Res 2017;194:20-8.

49. Blumer C, Haas D. Mechanism, regulation, and ecological role of bacterial cyanide biosynthesis. Arch Microbiol 2000;173(3):170-7. 
50. Bhutani N, Maheshwari R, Suneja P. Isolation and characterization of plant growth promoting endophytic bacteria isolated from Vigna radiata. Indian J Agric Res 2018;52(6):596-603.

51. Kumar V, Vir Pathak D, Singh Dudeja S, Saini R, Giri R, Narula S, et al. Legume nodule endophytes more diverse than endophytes from roots of legumes or non legumes in soils of Haryana, India. J Microbiol Biotechnol 2013;3:83-92.

52. Kuklinsky-Sobral J, Araújo WL, Mendes R, Geraldi IO, Pizzirani-Kleiner AA, Azevedo JL. Isolation and characterization of soybean-associated bacteria and their potential for plant growth promotion. Environ. Microbiol. 2004; 6(12):1244-1251.

\section{How to cite this article:}

Maheshwari R, Bhutani N, Suneja P. Screening and characterization of siderophore producing endophytic bacteria from Cicer arietinum and Pisum sativum plants. J Appl Biol Biotech 2019;7(05):7-14. 